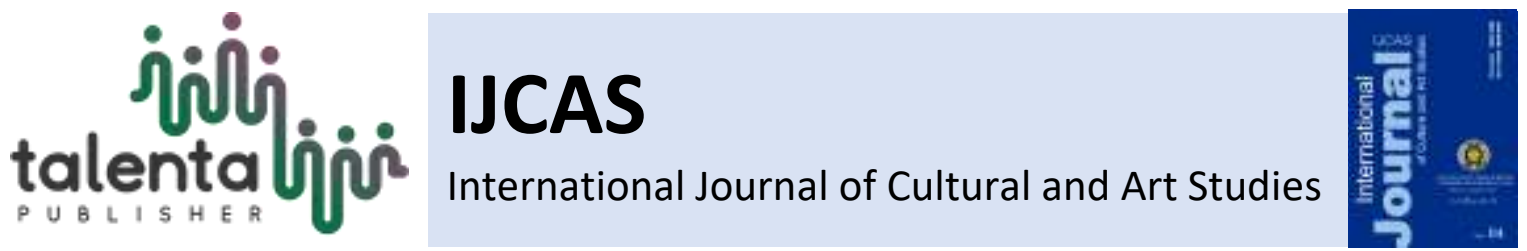

\title{
The Identity Issue of the Colonized and the Colonizer in Cloud Nine by Caryl Churchill
}

\author{
Liza Amalia Putri ${ }^{1 *}$, Katherine Clayton ${ }^{2}$ \\ ${ }^{1}$ Politeknik Negeri Media Kreatif, Jakarta, Indonesia. \\ ${ }^{2}$ University of Queensland, Queensland, Australia.
}

\begin{abstract}
One of the significant points in post-colonial literature is identity issues. The analysis of these identity issues should be focused not only on the colonized character but also the colonialist. It is obvious why post-colonial scholars are concerned with the colonized as they are the victims of colonialism. However, the colonizer must also face complex issues of identity when arriving in the colonial place. The purpose of this article is to examine the identity issues undergone by Joshua, the colonial subject, and by Clive, the colonizer, with reference to Cloud Nine by Caryl Churchill in the colonial period. The concept of hybridity by Homi Bhabha can explain the issue of Joshua's identity since he has "double" portrays of the identity as legacy of colonialism. Bhabha created the terms the "third space" or the "in-between" to describe the condition of the colonized people. Clive as the colonizer used to be a person without particular authority in his own country before arriving to the colonial land. Suddenly, his identity has shifted into someone who has privileges and authority. The colonizer's identity is not complete without the colonized. The colonized and the colonizer depend on each other. The colonized and the colonizer's identities will be fragmented if one of them is missing.
\end{abstract}

Keyword: Identity Issues, Colonialism, Post-Colonial Literature

Received 27 January 2020 | Revised 11 March 2020 | Accepted 26 April 2020

\section{Introduction}

The European colonial period was the era from the sixteenth century to the mid-twentieth century when several European powers established colonies in Africa, Asia, and America. Horvath [1] stated colonialism was a form of domination, or the control by individuals or groups over the territory and/or behavior of other individuals or groups. At present the colonial period has ended, and there is a new era called post-colonial. As Ashcroft, Griffiths, and Tiffin explained in The Empire Writes Back, the term post-colonial was used to cover all culture affected by the imperial process from the moment of colonization to the present day. How do we observe the impact of imperialism on a culture? Literature can reveal to people the truths and ideas embedded in a society. Literature enables the recording of thoughts in a way that is

\footnotetext{
*Corresponding author at: Politeknik Negeri Media Kreatif, Jakarta, Indonesia, Jl. Srengseng Sawah, Jagakarsa, Jakarta Selatan, Indonesia 12640.

E-mail address: liza.aputri@polimedia.ac.id
} 
accessible to future generations. Therefore, through post-colonial literature, we can observe the impact of the colonial era.

Caryl Churchill [2], a British playwright, produces Cloud Nine with colonialism as the central theme. In Act 1 of the play, she satirizes the phenomenon where oppressed people in colonized countries take on the identity of the colonizers. A white person cast Joshua, a black African slave of the white British master, as he identified himself with his master. Not only Joshua who must negotiate his identity in this colonial context. Clive, the British oppressor, must also negotiate a new identity in a colonial society when he shifts from being the mediocre man in his country to the 'father' of an alien community with full of authority. In the post-colonial literature, every character must negotiate the issue of identity, regardless of her or his background.

The purpose of this paper is to examine the identity issues undergone by Joshua as the colonial subject and by Clive as the colonizer with reference to Cloud Nine by Caryl Churchill in the colonial period. The concept of hybridity by Homi Bhabha can explain the issue of Joshua's identity since he has "double" portrays of the identity as legacy of colonialism. Bhabha created the terms the "third space" or the "in-between" to describe the condition of the colonized people as he said, "we will find those words with which we can speak of ourselves and others. And by exploring this hybridity, this 'Third Space', we may elude the politics of polarity" [2, p.209]. The colonizer used to be a person without particular authority in his own country before arriving to the colonial land. Suddenly, his identity has shifted into someone who has privileges and authority. Clive finds himself in a state of oblivion. He is not aware of the condition of people around him who are struggling against the hardships imposed by the colonial power. The colonizer's identity is not complete without the colonized. The colonized and the colonizer depend on each other. Clive uses Joshua to give him some information about what is happening within the family in the house and in the native community. The colonized and the colonizer's identities will be fragmented if one of them is missing. This phenomenon is aligned with the theory of hybridity by Homi Bhabha too.

Before discussing in depth, the issue of identity in the colonial era, it will be discussed the definition of colonialism based on Horvath and how he expands on the definition of colonialism previously created by other scholars. The discussion will cover the domination practice through intragroup and intergroup and clarify the difference between colonialism and imperialism. There will also be an explanation of the post-colonial era and the literature flourishing within that era, including the stages of literature development in a new colony: the first stage being texts brought into a colony produced by the representatives of the imperial power and the second stage being literature produced 'under imperial license' by 'natives' or 'outcast'. Finally, these concepts will be applied to an analysis of the identity issues faced by Joshua, the colonized, and Clive, the oppressor, in Caryl Churchill's play Cloud Nine. 


\section{Colonialism: the Definition, the Classification, and the Difference with Imperialism}

It is important to define colonialism before discussing in detail its practices. Horvath [1] stated colonialism was a form of domination, or the control by individuals or groups over the territory and/or behavior of other individuals or groups. Horvath contended that scholars had failed to provide adequate definitions of colonialism for many reasons. For example, some definitions did not convey a "cross-cultural perspective". Horvath argued by generalizing the experience of colonialism on the basis of one or two particular cases and disregarded the full range of reality of human history, such as developing colonialism theory only based on the Dutch controlling in Indonesia; "lack of theoretical perspective" signifying that lack of explanation may seem irrelevant; "lack of flexibility in definitions of colonialism" meaning definitions and classifications should fit new findings so they have competent flexibility to accept articulation; "an ultraconservative attitude toward words and their meanings" showing how a small concept can be developed into bigger thing, such as the concept of imperialism was initially applied on British foreign policy only.

Colonialism refers to group domination, and the two basic types of group are intergroup and intragroup domination. The domination process in a culturally heterogenous society is called intergroup domination, while intragroup domination refers to the domination process in a culturally homogenous society. We can see the example of intergroup and intragroup domination in Britain. The domination of the Welsh, Irish, and Scots by the English was an example of intergroup domination where a single authority exerted power over a culturally heterogeneous group of people. The existence of a hierarchical arrangement of power, wealth, and status among groups within English society is an example of intragroup domination.

It is important that the differences between colonialism and imperialism is understood as people often use the terms interchangeably. They are, in fact, two different words and have a slight difference in meaning. Both terms convey the concept of economic and political domination and oppression of the colonized/the other. However, the key difference between colonialism and imperialism is the presence or absence of significant numbers of permanent settlers in the colony from the colonizing power. Latin America, North America, Australia, New Zealand, South Africa, and the Asian part of the Soviet Union dominated by European authority were examples of colonization because permanent settlers moved from the European country to the colonies. In contrast, places dominated by the colonizing power but not settled by people from the colonizing country were imperialized. Most of Africa and Asia are examples of imperialism. 
The post-colonial era is the era that proceeded the colonial period. In the context of this paper, Ashcroft, Griffiths, and Tiffin state [3] the term post-colonial is used "to cover all the culture affected by the imperial process from the moment of colonization to the present day. This is because there is a continuity of preoccupations throughout the historical process initiated by European imperial aggression". Therefore, the literatures of African countries, Australia, Bangladesh, Canada, Carribean countries, India, Malaysia, Malta, New Zealand, Pakistan, Singapore, South Pacific Island countries, and Sri Lanka are post-colonial literatures. The authors also point out literature of USA should be placed in the category, but perhaps because of its current position of power, and the neo-colonizing role it has played, its post-colonial nature has not been generally recognized. As we know, literature can relate people with larger truths and ideas in a society and create a way to write down the thoughts and experiences in a way that is accessible to others so that it can be used or seen again in the future. Therefore, through postcolonial literature, we can observe the mark left by the colonial era.

\section{Development of Post-colonial Literatures}

Ashcroft, Griffiths, and Tiffin [3] state there are several stages to the development of postcolonial literature: "stages both of national or regional consciousness and of the project of asserting difference from the imperial center". During the colonial era, literate aristocracy identified with the colonial power generated writing in the language of the colonizer. Because of this, the first texts authored in the colonies were produced by the representatives of the imperial power. These kinds of texts could not express an understanding the native culture. The texts privilege the imperial center even though they are able to describe the landscape, custom, and language in detail with emphasizing the 'home' over the 'native', the 'metropolitan' over the 'provincial' or 'colonial', and so forth.

The literature produced 'under imperial license' by 'natives' or 'outcast' is the second stage of production in the evolving discourse of the post-colonial. This stage of post-colonial literature development signifies that by the very fact of writing in the language of the dominant culture that they have temporarily or permanently entered a specific and privileged class endowed with the language, education, and leisure necessary to produce such works".

\section{$5 \quad$ Cloud Nine by Caryl Churchill}

Caryl Churchill is a British playwright and has produced many plays with mostly feminism and post-colonialism as the themes. The first act of Cloud Nine (1979) clearly elicits the theme of colonialism as it is set in a British Colony in Africa during the Victorian era. Churchill is an author writing in the second stage of post-colonial literature production as she wrote the play 
during the leadership of Margaret Thatcher who became the prime minister in 1979, well after the Victorian era. Although her background indicates she is a playwright 'under imperial license', she uses her play to criticize how Victorian traditions and values continued to influence the society and culture during the conservative rule of Thatcher. The play was inspired by the various forms of oppression Churchill saw as remaining, at that time, within British society.

In the Act 1 of Cloud Nine, besides highlighting colonial oppression in Africa ruled by British, Churchill also satirizes the phenomenon where oppressed people in colonized countries take on the identity of the colonizers. Joshua was a black African slave of the white British master, and he was cast by a white person as he identified himself with his master. Another analysis dealing with identity from this play is that the colonizer, Clive, also has identity issue similar as the colonized Joshua.

\section{The colonized Identity Issue in Cloud Nine}

From the beginning of Cloud Nine, the audience is aware there are several opposite groupings among the characters. Clive introduced himself as a father to the natives and to his own family. He also introduces Joshua by saying "My boy's a jewel. Really has the knack. You'd hardly notice that the fellow's black." By noticing the words "native" and "black," we know there is unequal relationship between Clive as the representative of the imperialist and Joshua as the imperial subject; between the foreigner and the native; between the white and the black. It is clearly seen the separation of the two differently culturally groups putting the colonizer at the top of the colonized. These pairs of terms or concepts which are opposite in meaning, such as the colonizer and the colonized, is called a binary opposition system.

The binary opposition system is created by Western Europe to describe "us" and "them" or to divide the world into the "Occident" and the "Orient", which are developed from the term Orientalism by Edward Said. The idea of Orientalism by Said [4] is based on his identification of the assumptions made by Western people about the Orient, such as Oriental people are antiWestern, irrational, and threatening. The construction of these assumptions is the opposite of what Westerners think about themselves, so they define the Orient as the Other, or who they are not. What makes it harmful is that these assumptions are considered as truth. This thought, of course, will impact the relationship between them and their ideologies. Said also emphasizes that Western Europeans believed "the Orient existed for the West". This concept means the relationship is mutually essential, as each cannot exist without the other.

Besides binary opposition, post-colonial theory also investigates colonized people negotiating with their own identity and culture. In post-colonial literature, colonized people tend to have "double" portrayal of their identity as a consequence of the legacy of colonialism. The doubleness of their identity means they must navigate the dynamics of two cultures: their own 
and the western colonizing culture. Homi Bhabha [5] created the terms the "third space" or the "in-between" to describe this situation. He says "we will find those words with which we can speak of ourselves and others. And by exploring this hybridity, this 'Third Space', we may elude the politics of polarity". The concept of hybridity has an important role in post-colonial theory since it refers to integrating the cultural signs and practices from both the colonizing and the colonized cultures.

The combination of native culture and western colonizing culture leads to a crisis of identity for both the colonized and the colonizer. Empire Writes Back states, it is at the point of displacement that "postcolonial crisis of identity emerges". There is an internal conflict for colonized people who are caught between western and indigenous cultures. We can see this in the character of Joshua in the play. Churchill uses Joshua's character in the play to symbolize the postcolonial crisis of identity experienced by colonized people. Joshua is devoid of a unified self: under the processes of colonization has lost his identity. He does not know who he is and where he belongs to.

\section{The Colonizer Identity Issue in Cloud Nine}

In every post-colonial text, there are, at least, two opposite characters narrated: the one who is being colonized and who is colonizing. Typically, the analysis of characters in post-colonial texts focuses on the identity dynamics of the colonized. However, the colonizer also has identity issues, which they must navigate.

In post-colonial literate, the colonizer is usually represented as an ordinary person in his own country before arriving to the colonial land. When arriving in the colony, he suddenly acquires authority. This causes changes to his identity as goes from a person without authority and wealth to a colonial ruler in command of great wealth and authority. The speed of the transition is disconcerting because he acquires these privileges simultaneously. Like the colonized, he discovers himself in a state of confusion regarding both his identity and the context he now finds himself in. He is not aware of the condition of the people around him who are struggling against the hardships.

The colonizer's identity is not complete without the colonized. The colonized and the colonizer are complementary and interdependent. We can see this in Cloud Nine with Clive and Joshua. Clive uses Joshua to give him some information about what is happening within the family in the house and in the native community.

Clive: "Thank you, Joshua. I'll be sorry to have to replace them."

Joshua: "They carry knives."

Clive: "Thank you, Joshua." 
Joshua: “And, sir. Your wife."

Clive: “Ah, yes?”

Joshua: "She also thinks Harry Bagley is a fine man."

The colonizer knows that he has done an offense against moral, and he should deal with his feeling. He does not want to leave his privileges, but he does not want to conduct a morally wrong or illegal act. Therefore, he searches for justification. He attempts to make himself sure what he has done is right. He thinks he deserves sympathy from people because he has done good things by civilizing the colonized who used to be uncivilized. In Cloud Nine, Clive tries to convince the audience what he does to the native in Africa and to his country is not unfair and patriotic. As he says in the beginning of the play:

Clive: "This is my family. Though far from home, we serve the Queen wherever we may roam. I am a father to the natives here. and father to my family so dear."

The colonized and the colonizer's identities in post-colonial literature are not independent from each other. The identities will be fragmented if one of them is missing. This phenomenon is aligned with the theory of hybridity by Homi Bhabha [6]:

"Hybridity shifts power, questions discursive authority, and suggests that colonial discourse is never wholly in the control of the colonizer. Its authority is always inflected, split, syncretized and to an extent menaced by its confrontation with its object."

In the post-colonial literature, every character has identity issues, which they must navigate, regardless of whether they are the coloniseror the colonized. In addition, whatever age of the colonial generation, even the youngest generation, in the colonial family it is identified as a colonizer. The baby who is being born into the colonizer family will be regarded as a colonizer. It is the same case as colonized people. They who were born under colonized identity are identified with many stereotypes of being a colonized since their birth.

\section{Conclusion}

Identity issues are one of the significant points in post-colonial literature, and the analysis of these identity issues should be focused not only on the colonized character, but also the colonialist. It is clear why post-colonial scholars focus on the colonized as they are the victims of colonialism. However, the colonizer must also face complex issues of identity when arriving in the colonial place. Both the colonial subject and the colonizer in the post-colonial literature face the same problem with identity because their identity is re-established and re-assembled during the oppression period. 


\section{REFERENCES}

[1] R. J. Horvath, "A Definition of Colonialism," Current Anthropology, Vol 13, no.1, pp. 45-57, 1972.

[2] C. Churchill, Cloud Nine. New York: Routledge, 1980.

[3] B. Ashcroft, G. Griffiths and H.M. Tiffin, The Empire Writes Back: Theory and Practice in Post-Colonial Literatures. London: Routledge, 1989.

[4] E. Said, Orientalism. London: Vintage, 1978.

[5] H. K. Bhabha, "Of Mimicry and Man: The Ambivalence of Colonial Discourse", October 28, 1984.

[6] H. K. Bhabha, The Location of Culture. London: Routledge, 1994. 